\title{
SUPPORT OF DEVELOPMENT OF NON-PROFIT ORGANISATIONS THROUGH SPECIAL TRAINING PROGRAMS FOR THEIR MANAGERS
}

\author{
Irena MIKOVA, Lenka KOMARKOVA, Pavel PUDIL* \\ Faculty of Management, University of Economics, Prague, \\ Jarosovska 1117/II, 377 01, Jindrichuv Hradec, Czech Republic \\ *E-mail: pudil@fm.vse.cz
}

\begin{abstract}
Purpose - the paper is concerned with the issue of further education in non-profit organisations (NPOs) using training programs for their managers (TPM) and their impact on organisation development. The study aim was to find out whether and how the existence of TPM in the organisation depends on the founder, sector and duration of its economic activity. It also investigates which competencies the NPO managers perceive as the key ones.

Research methodology - the study, based on the research questionnaire, included 69 NPOs. The dependence of TPM on defined characteristics has been assessed using Pearson's chi-squared test or logistic regression.

Conclusions (findings) - the results indicate that the usage of TPM is related to the size and founder of NPO. The other examined characteristics do not have a statistically significant effect. Furthermore, competencies considered by NPO managers as the most important were specified.
\end{abstract}

Research limitations - follow from the size of the research sample.

Practical implications - also, NPOs should focus on developing competencies mentioned in the study and evaluate them using impacts on the results of work activities.

Originality/Value - the influence of training of managers on the development of NPOs is not sufficiently addressed in the literature.

Keywords: development of non-profit organisations, further education and training, programs for managers, managers' competencies.

JEL Classification: I25.

Conference topic: Contemporary Organizations Development Management.

\section{Introduction}

The competencies, skills, and knowledge of managers are reflected in their activities and thus in the direction and success of the development of the whole organisation. The paper, therefore, deals with the issue of further education in non-profit organizations (NPOs), with an emphasis on education and training programs for managers, as deepening and developing employees'/managers' competencies can be seen as part of the long-term strategy needed for the development of each organization and the way of its sustainability. The focus of this research was on the characteristics of the NPO (size, type, sector and duration of economic activity) as well as the evaluation and monitoring of the impact of the mentioned training. Though it is possible to evaluate the training already during its implementation, evaluation with a time lag is much more important for the organisation. The reason is that only then the new competencies and the acquired skills of the employees in their activities are fully manifested, together with demonstrable impacts on the results of the work. The effectiveness of education in an organisation can then be assessed by fulfilling the goals of education which should correspond to the organisation's goals. Assessment can be done using the tools to measure the success of the organisation's activities, e.g., Key Performance Indicators (Gabčanová, 2012).

The main objectives of this study to the just mentioned facts are:

- to confirm the dependence of the existence of further professional education in NPOs designated for managers on the following characteristics - the type, size, sector of economic activity, and duration of activity of the organisation; 
- to assess the relationship between the existence of education and training for managers, and their evaluation at the level of the impact of education on the results of the work of trained employees in the organisation (according to the Kirkpatrick model education levels, see D. L. Kirkpatrick \& J. D. Kirkpatrick, 2006);

- to find out which professional competencies NPO employees consider to be the most important for their performance and to compare whether there is a difference in views on the three most essential competencies between the groups of staff members and managers.

The research questions corresponding to these three main objectives are formulated at the end of this section.

While NPOs are not intended to generate profits, as one way to ensure superiority over competitors, it does not mean that they should not seek to make effective use of the resources they have. Molek (2011) claims that the quality of NPO's performance is assessed to be the difference between benefits and costs, with the maximisation of the difference not being projected to the profit, but to the extent of meeting the public's interests and the efficient use of resources. Also, the quality of the services provided is related to the effective management and managerial competencies enabling the transfer of the latest knowledge from the fields of interest and their application to the daily practice. This is facilitated by lifelong learning and professional education, including its evaluation and monitoring of its effects for the organisation. The evaluation is carried out at several levels. Tureckiová (2004) recommends assessing further education and training of staff in public organisations and NPOs according to five levels. She suggests that the fifth level does not necessarily have to be the usually used ROI indicator (according to Phillips (1996)'s proposal) but the value level, assessing the impact on the development of the organization's objectives and impact on "changing the quality of life" of the external environment (the community).

It is, therefore, apparent that increasing demands on executives who carry the core responsibility for the whole organisation increase the pressure on their qualifications and competencies. Ensuring optimal status and sustainability in an organisation can only be achieved through systematic development and further professional training related to acquiring and disseminating the necessary knowledge and skills. The education process is described by Mumford and Gold (2004) as the right way to improve the effectiveness of managers. Strategies focusing on the development and training of managers should be based on the fact that the success of corporate education and development programs depends on how much the development of an individual's potential is in line with the primary goals and tasks of the organisation. The authors emphasise that the underlying philosophy of each organisation should be not only to make effective use of existing managers' experience but also to stimulate their development through further education, to influence knowledge and the full use of skills. However, as Mumford (2006) points out, formal management processes do not always work as efficiently as many expect. The cause is highlighted by the emphasis on planning, while efforts to use managers' experience to identify educational needs correctly are often underestimated. Also, as Drucker (2002) states, each organisation can and should systematically offer its managers incentives and opportunities for their further development. The success of the manager, of course, also determines the extent to which he can apply appropriately the managerial skills gained to the organisation's goals.

The direction of organisations is influenced by some other factors such as political and economic development, the level of life in society, its structure, changes in legislation, and often just public pressure. At the same time, the public expects the organisation to adapt flexibly to changes and their management to respond appropriately to external influences, to eliminate potential negative impacts and take appropriate action towards long-term sustainability (Krajáč, 2005). The fact, how much are their actions effective and correspond to the organisation's objectives, is related in particular to the current knowledge of employees and their ability to adapt to new trends. This will be facilitated by introducing a system of training of employees and managers into the overall strategy of the organisation.

When selecting an appropriate strategy for non-profit sector managers, Kong (2009)'s article can be of help. The author examines five key strategic concepts of management within a non-profit context and determines which one is most applicable to the non-profit sector. Kong (2009), in connection with his previous research, notes that very little research focuses on the application of the concept of intellectual capital (IC) and the processes of learning in social service NPOs. Even in these types of organisations, it is a necessity to learn new ways, to acquire new knowledge and to abandon the outdated knowledge. The author argues theoretically the possibilities of using IC as a conceptual framework that can help managers develop the learning culture and change the social service NPOs into dynamic learning organisations.

In the case of the public sphere, focusing on social activity, the success of organisations depends on the quality of the services provided and is closely related to the level of professional competence of their personnel. The topic of frequent present debates is, therefore, the issue of efficiency of the public sector and the related implementation of management methods in public administration organisations (Kopfová, 2012). Moreover, Kerlesová (2010) notes that public institutions, through the introduction of education programs into long-term strategies, can also affect employee's loyalty and reduce the financial costs associated with fluctuation, increase accountability, efficiency, and professionalism of employees. Positive impacts can then be seen in social and communication skills when dealing with citizens, or in ways of leading people in organisations themselves. In agreement with Kerlesová (2010), as the most frequent reasons for implementing further education and support for the development of public administration employees can 
be considered: providing better quality services, professional approach, learning new knowledge about the use of information technologies, changing ways of managing the institution and acquiring skills for their correct application, the growing control of officials by the public. These are important factors that can be understood as the indicators of the effectiveness of education in the organisation itself.

The special training area for public sector personnel is, as has already been mentioned, the training of senior staff. It is necessary to point out that the education of state officials is embedded in the Czech Republic in the legislation. The managers or those who are preparing for a managerial position extend in this way knowledge and experience gained by practice in the field. Through this training, they acquire and deepen the knowledge of the basics of management and, particularly, managing the public administration staff. Supporting the process of training for public sector employees has a long tradition in the case of countries in the European Union (EU).

An example is the Phare project (1996-1999), which has been followed by projects supporting the economic growth and education of citizens in EU countries through so-called operational programs. The Human Resources area is funded by the European Union Structural Funds (European Social Fund). The issues of transition countries, the tendency towards European integration or global globalisation are referred to by Ismaili and Latifi (2012) as factors with a significant impact on the reform of the public and private sectors, especially for countries entering the EU. Accession to the EU is directly linked to reforms of the transparent and democratic functioning of the public administration. In particular, through a case study, Ismaili and Latifi (2012) explore the importance of education for the current trend of public administration reforms and the impact of education on its transparent and democratic functioning.

However, our research is not limited to organisations of the public (governmental) non-profit sector, i.e., budget and contributory organisations, but the research sample also consists of non-governmental (private) NPOs. Even in the case of non-governmental NPOs, there is a scope for further professional training. Here we talk about so-called supervision. Supervision is another type of education in which employees can develop professionally and create good practices and attitudes for their work (Čermáková \& Johnová, 2002; Fuxová, 2011). Supervision brings the transfer of experience and professional development of individuals in the framework of the whole group (Matoušek, 2003; Fuxová, 2011). The supervisor is responsible for effective supervision and positive benefits, so his/her qualifications, skills, continuously supplemented knowledge and experience are an essential aspect of the quality and success of his/her work. According to Hay and Brown (2015), one of the key actors in the area of education and training for social work are the managers of agencies that realise the practice. Since managers are directly involved in social work, they can better decide which graduates they need and what specific assumptions for social work, including flexibility, humility, trust, and resilience they require from the graduates. Managers in this context play the role of supporters, mentors; they act as intermediaries, potential employers, and sometimes evaluators of students preparing for work in the social sphere.

Hardina and Montana (2011) describe the results of a national survey of social services managers. Respondents were asked to identify the theories and management models they acquired through education and apply them to practice. The results suggest that most social service managers apply approaches based on empowering employees and allow subordinate employees to participate in organisational management. Boyle, Donald, Dean, Conrad, and Mutch (2007) assess the activity of 108 NPOs that contribute to the support of mental health in the communities of the Brisbane metropolitan area. They note that the potential of these organisations is not fully exploited as only $34 \%$ of organisations perceive education and development as a need and that further professional training is not systematically implemented in the organisation's strategy. Also, management is only marginally concerned with the systematic evaluation of its activities and prefers rather informal feedback from clients.

The competencies of social services managers and personnel are studied by Shanks, Lundström, and Bergmark (2014). Their research aimed to find out what they consider to be the main source of their knowledge and to contribute as much as possible to their managerial competencies. Findings show that most managers have undergone managerial training at work and that most rely on methods that can be described as practice-oriented to managerial competencies. A practical orientation is assessed in relation to the nature of managerial training in practice, the extent of knowledge of the principles of social work and takes into account the lack of post-graduate managerial education offered by Swedish schools of social work. Luiz (2012) presents a synthesis of research on the educational dimension of the practice of social services in connection with the state training programs for social assistance managers in Brazil in the period 2000-2004. The author contributes to the debate on ethics, politics, and education of managers and consultants from various areas of social assistance in Brazil. In the form of interviews with social services experts and trained consultants, he analyses training and practice in the social sphere and documents the fundamentals of social emancipation.

Giffords (2009) also focused his research on the social services environment. His study is interesting by assessing both social commitment and professional commitment to social workers along with work assignments. Commitment to organisation and commitment to the profession is assessed in relation to variables of the professional environment, demographic indicators, employment time and factors determined by the organisation (e.g. benefits, etc.). On a sample made up of members of the National Association of Social Workers, Giffords (2009) concluded that the identified factors significantly contribute to the organisational and professional deployment of social workers, their commitment 
and engagement. A necessary prerequisite, however, is that social service managers are equipped with the necessary skills and abilities to enable them to find and favour the desired factors.

Supervision, as a relatively new area introduced in Romanian social care institutions, is discussed in Caras and Sandu (2014)'s paper, which deals with the role of supervision in the process of professional development of social workers. It is based on a functioning two-way relationship between people with extensive professional experience and workers professionally involved in dealing with specific cases. This is confirmed by the fact that supervision in social services is considered an educational and administrative process aimed to provide support. The research was conducted in an elite non-governmental organisation in north-eastern Romania in a child protection area. The indicator of the effectiveness of the supervision process can be the quality of social work practice in the organisation. The authors collected the data through interviews with the participants and concluded that effective supervision determines the existing relationship between its participants, the quality of the services provided, and the training provided.

The importance of the role of executives in social services is also highlighted by Carpenter, Webb, Bostock, and Coomber (2012). Their research has shown that appropriate methods of management and effective supervision are an important prerequisite for employees' job satisfaction and determine their commitment to the organisation. Managers equipped by appropriate competencies and interested in employees are prerequisites that help to reduce personal changes due to staff leaving. This fact is also related to the level of the perceived support provided to employees by the management of the organisation. In this study, the importance of applying managerial education and supervision in social work can be argued, as they correlate with the perceived efficiency of workers. The publication of Kadushin and Harkness (2014) summarises the issue of human supervision in the light of changes caused by development in public health and social care policy, coupled with the growing pressure to effectively and responsibly manage health and social services in private and public sector. It deals with personnel management issues, security personnel, solves burnout problems, and besides performance evaluation methods, it also deals with the competencies needed for effective supervision in the field of social services.

From the previous, we conclude that senior managers are the creators of corporate strategies that are projected into the performance of the organisation, though often indirectly. The success rate of the applied strategy then corresponds to the capabilities of the creators themselves. Qualified managers possessing needed competencies have the prerequisites to efficiently use their experience and knowledge, to work with the necessary information and thus to influence individual and organisational prosperity (Marinič, 2008; Novák, 2012). Managerial competencies can be defined according to Veteška (2010) as the ability of an individual to behave according to the requirements of the performed work, according to the conditions of the external economic and social environment and the internal climate of the organisation and to produce the desired and expected results.

Integration of senior managers' personal experience related to the further development of leaders in public, nonprofit and private organisations in Ireland to the current theory of leadership is brought about by McDermott, Kidney, and Flood (2011). Through a pilot study, the authors acknowledge the importance of competencies and other ways of their development in case of leaders, with an emphasis on emotional management skills, teamwork, and adaptation to contextual requirements. Contextual factors are then reflected in the leadership style itself. Also, Thach and Thompson (2007) aim to identify the differences, if any, in the leadership style, behaviour, and skills for managing performance among California leaders in public/non-profit and profit organisations. Their study suggests the universality of the competencies of managers in both the profitable and the public or non-profit sectors in characteristics such as honesty and integrity put in the first place, teamwork to the second and motivation for further development to the third place. However, the results also showed some differences in customer service approaches. Managers of both profit and nonprofit organizations have consistently identified customer service and employees as the key factors in managing business performance, however, leaders of for-profit companies put their emphasis on customer service as they are a means to generate revenue and profit, and therefore support employees' education and development as an integral part of the strategy ensuring the quality. Leaders of public/non-profit organisations place primary emphasis on employees and opportunities to develop their competencies, as this is reflected in their activities and has an impact on the satisfaction of clients as well. According to the authors, just this difference in thinking and attitudes to the preferred employeecustomer ranking may be an important factor in distinguishing training programs for individual sectors.

Professional competencies can be understood as a preferred term for qualification, which is supposed to be their part. These competencies are demonstrated by the degree of success of the activity being performed. The definition of competencies and the identification of a group of managerial skills have been addressed by a number of authors, e.g. Boyatzis (1982), Goleman (2006), L. M. Spencer and S. M. Spencer (1993), Prahalad and Hamel (1994). Occupational competencies typically define the areas in which the required activities are directed, taking into account the specifics of the work performed. In this way, the professional competencies of managers can be specified. One such division is offered by Katz (2009) in Skills of an Effective Administrator. He defines managerial skills within the following groups - technical, human and conceptual. According to his predefined structure of managerial competencies, the higher the managerial position within the hierarchy, the more emphasis on conceptual managerial competencies. Our research attempts to confirm that this statement is valid also in the public sector. A similar division is given by Tureckiová (2009) who defines four components of professional competence: Professional or technical competence - adequate formal qualification and presupposes knowledge of the field; Methodical or conceptual, enabling them to learn flexibly 
and effectively new knowledge and procedures; Social and Personal competencies. The latter two are also referred to as soft skills, while the first two refer to hard skills. For this study, we were inspired by the division of Katz (2009), with the group of humans, by many referred to as so-called soft skills, which was divided into personality characteristics and interpersonal skills, similarly to Tureckiová (2009).

Prugsamatz (2010) states that NPOs can be perceived as learning organisations if they have established learning processes and learning systems at the individual, team and organisational levels. The fact that these processes include motivation to learn, team dynamics and organisational culture helps to the long-term sustainability of learning throughout the organisation. All the previous mentioned findings concerning the impact of continuing professional education on the development of organisations and our research activities in the field have inspired us to focus more on the public sector and NPOs. The aim of this study, specified at the beginning of the paper, can be formulated using the following three research questions:

-RQ1: How does the degree of existence of special education and training programs for NPOs managers differ concerning the essential organisation characteristics?

-RQ2: Is there an association between the existence of managers education and training program, and evaluation of education impacts in NPOs?

-RQ3: What three competencies are perceived as the most important from the perspective of managers and employees of NPOs?

\section{Data and methods}

The pilot study included 69 NPOs. The required data was obtained through a questionnaire survey. We have paid more attention to the selected characteristics of these organisations to demonstrate the relevance of training programs aimed at developing managers, provided they exist in an organisation. The investigated characteristics of organizations were the type of founder (state, self-government, others), the size (the number of employees), duration of activity (the number of years), the sector of economic activity according to CZ-NACE classification, and finally the existence of subsequent evaluation of the results of education (i.e., the 4th level of education evaluation based on the Kirkpatrick model - see, e.g. D. L. Kirkpatrick \& J. D. Kirkpatrick, 2006).

Concerning the small sample size, only two categories of organisations according to their size were considered, with up to 249 employees (micro, small and medium-sized organisations) and over 249 employees (large organisations). In the case of economic activity, only three categories were distinguished, denoted in the following way:

-Administration: NACE sector O - Public administration and defence; compulsory social security;

- Education: NACE sector P - Education;

- Other: Other services, namely NACE sectors from G to U.

Table 1 represents a more detailed division of organisations by size, Table 2 distinguishes individual types of organisations according to the sector of their economic activity, and Table 3 characterises the organisations with regard to the time of their existence.

Table 1. Number of organizations according to the type (with respect to the founder) and the size (source: created by authors)

\begin{tabular}{|l|c|c|c|}
\hline \multicolumn{1}{|c|}{ Organization Type/Size } & $<250$ employees & $\geq 250$ employees & Total \\
\hline Central-governmental & $5(7.2 \%)$ & $28(40.6 \%)$ & $33(47.8 \%)$ \\
\hline Local-governmental & $21(30.4 \%)$ & $7(10.1 \%)$ & $28(40.6 \%)$ \\
\hline Non-governmental & $7(10.1 \%)$ & $1(1.4 \%)$ & $8(11.6 \%)$ \\
\hline Total & $33(47.8 \%)$ & $36(52.2 \%)$ & $69(100.0 \%)$ \\
\hline
\end{tabular}

Table 2. Number of organizations according to the type and the economic activity sector (source: created by authors)

\begin{tabular}{|l|c|c|c|c|}
\hline Organization Type/Sector & Administration & Education & Other & Total \\
\hline Central-governmental & $19(27.5 \%)$ & $7(10.1 \%)$ & $7(10.1 \%)$ & $33(47.8 \%)$ \\
\hline Local-governmental & $18(26.1 \%)$ & $4(5.8 \%)$ & $6(8.7 \%)$ & $28(40.6 \%)$ \\
\hline Non-governmental & $0(0.0 \%)$ & $0(0.0 \%)$ & $8(11.6 \%)$ & $8(11.6 \%)$ \\
\hline Total & $37(53.6 \%)$ & $11(15.9 \%)$ & $20(30.4 \%)$ & $69(100.0 \%)$ \\
\hline
\end{tabular}


Mikova, I.; Komarkova, L.; Pudil, P. 2019. Support of development of non-profit organisations through special training programs for their managers

Table 3. Descriptive statistics for activity duration of organizations (source: created by authors)

\begin{tabular}{|l|c|c|c|c|}
\hline Organization Type/Activity Duration & Minimum & Mean & Median & Maximum \\
\hline Central-governmental & 1 & 20.5 & 23.0 & 46 \\
\hline Local-governmental & 8 & 31.1 & 27.5 & 45 \\
\hline Non-governmental & 1 & 11.4 & 7.0 & 27 \\
\hline Total & 1 & 23.7 & 23.0 & 46 \\
\hline
\end{tabular}

Targeted training of managers in the organisation was investigated using yes-no questions. Only pairwise relationships were examined with respect to the sample size. The Pearson chi-squared test of independence analysed the dependence of the existence of special training and training programs for managers on the type, size, and sector of economic activity. In the case of a violated assumption for expected frequencies, the p-value was determined using the Monte Carlo simulation based on 100000 replicates. Logistic regression was used to assess the relationship between the existence of specialised training for managers in the organisation and the duration of its economic activity, which is a quantitative variable. The statistical significance of the results was assessed at a standard 5\% significance level.

Among the participants of the questionnaire survey, focused on the further education of managers in the nonprofit sector, two groups of respondents from this sector could have been identified according to the position within the company hierarchy, namely managers and general staff. Although for most of our characteristics, the respondents' job positions were not relevant, this additional distinction enabled to make an interesting comparison concerning the identification of critical competencies. Using open questions in our questionnaire, the respondents gave their opinion on the personality characteristics, knowledge and skills they think are most important for their position. Key competencies were then identified using content analysis and the division of competencies according to Katz (2009), or Tureckiová (2009), respectively.

\section{Results}

Tables $4-6$ show contingency tables for investigated variables and related statistical tests for investigation of their possible association. The results in Tables 4 and 5 show that a statistically significant difference in the use of special education for managers was detected in the case of organisation size $(\mathrm{p}=0.012)$. In particular, according to Table 5 large organisations have this type of education almost 1.9 times more often. Further, Table 4 suggests a possible difference concerning the distinction of organisations by the type of founder $(p=0.065)$. However, it should be noted that this result may be distorted by the fact that the state-owned organisations are mostly large. The results in Table 6 indicate that the intersectoral difference is not statistically significant $(\mathrm{p}=0.258)$. Nevertheless, it is worthy of noting that the education of managers in educational institutions is not given the same attention as in the other two categories (Administration, Other).

Table 4. Education for Managers vs Organization Type: Absolute (and column relative) frequencies; Pearson's chi-squared test with the simulated p-value: $\mathbf{p}=\mathbf{0 . 0 6 5}$ (source: created by authors)

\begin{tabular}{|c|c|c|c|}
\hline Education/Organization Type & Central-governmental & Local-governmental & Non-governmental \\
\hline Yes & $22(66.7 \%)$ & $13(46.4 \%)$ & $2(25.0 \%)$ \\
\hline No & $11(33.3 \%)$ & $15(53.6 \%)$ & $6(75.0 \%)$ \\
\hline
\end{tabular}

Table 5. Education for Managers vs Organization Size: Absolute (and column relative) frequencies; Pearson's chi-squared test with Yates's continuity correction: $\mathbf{p}=\mathbf{0 . 0 1 2}$ (source: created by authors)

\begin{tabular}{|c|c|c|}
\hline Education/Organization Size & $<250$ employees & $\geq 250$ employees \\
\hline Yes & $12(36.4 \%)$ & $25(69.4 \%)$ \\
\hline No & $21(63.6 \%)$ & $11(30.6 \%)$ \\
\hline
\end{tabular}

Table 6. Education for Managers vs Sector of Economic Activity: Absolute (and column relative) frequencies; Pearson's chi-squared test: $\mathbf{p}=\mathbf{0 . 2 5 8}$ (source: created by authors)

\begin{tabular}{|c|c|c|c|}
\hline Education/Economic Sector: & Administration & Education & Other \\
\hline Yes & $23(62.2 \%)$ & $4(36.4 \%)$ & $10(47.6 \%)$ \\
\hline No & $14(37.8 \%)$ & $7(63.6 \%)$ & $11(52.4 \%)$ \\
\hline
\end{tabular}


Table 7 presents the results of logistic regression for modelling the probability of the existence of managerial education in NPO in dependence on the activity duration of an organisation. The influence of the activity duration of the organisation on the existence of education of its managers has not been indicated by our study $(p=0.569)$. For a change, Table 8 describes the distribution of effect or impact evaluation in dependence on the existence of managerial education. Contrary to the duration of activity, the results in Table 8 also show that there is a statistically significant relationship between the evaluation of the impacts of education in the organisation and the existence of an educational program for managers $(p=0.009)$. Only $15(21.7 \%)$ organisations in our pilot study evaluated the effects/results of education. It is necessary to clarify that, as stated in the introduction, evaluation means the assessment of the impact of education on the results of the work of the trained employees of the organisation (i.e., the 4th level of the Kirkpatrick education evaluation model).

Table 7. Education for Managers (response) vs Duration of Activity (predictor): Basic results of logistic regression; estimates for both regression parameters and odds ratio (OR) for predictor; related confidence intervals (CIs) and Wald's tests (source: created by authors)

\begin{tabular}{|c|c|c|c|c|c|}
\hline Parameter & Estimate & $95 \%$ CI & Estimate for OR & $95 \%$ CI for OR & P-value \\
\hline$\beta_{\mathbf{0}}$ (Intercept) & 0.39 & $(-0.58,1.35)$ & - & - & 0.430 \\
\hline$\beta_{\mathbf{1}}$ (Duration) & -0.01 & $(-0.05,0.03)$ & 0.99 & $(0.96,1.03)$ & $\mathbf{0 . 5 6 9}$ \\
\hline
\end{tabular}

Table 8. Results Evaluation vs Education for Managers: Absolute (and row relative) frequencies; Pearson's chi-squared test with Yates's continuity correction: $\mathbf{p}=\mathbf{0 . 0 0 9}$ (source: created by authors)

\begin{tabular}{|c|c|c|}
\hline Education/Results Evaluation & Yes & No \\
\hline Yes & $13(35.1 \%)$ & $24(64.9 \%)$ \\
\hline No & $2(0.1 \%)$ & $30(93.8 \%)$ \\
\hline
\end{tabular}

Furthermore, we investigated particular forms of such impacts. As the most frequent ones, the following forms of impact on the organisation and its development have been found:

- Time spent in education;

- Skills of the employees and the number of certificates obtained in the required fields;

- Employee motivation index;

- Employee satisfaction and loyalty;

- Employee turnover.

Further professional education in organisations should correspond not only to the objectives of the organisation but should result from the training needs of the employees themselves. These should be in line with the knowledge, skills, and competencies needed to practice the profession. In our research, we have therefore aimed to find out the opinion of the employees themselves about which competencies they consider to be the most important. Key competencies based on respondents' answers are summarised in Table 9.

Table 9. Comparison of the frequency of managers' and staff members' views on the most important competencies (source: created by authors)

\begin{tabular}{|c|c|c|}
\hline Competencies/Employee Position & Managers & Staff members \\
\hline Conceptual - Managerial & $\begin{array}{l}\text { Decision-making and management } \\
18\end{array}$ & - \\
\hline Interpersonal & $\begin{array}{l}\text { Communication and dealing with people } \\
15\end{array}$ & $\begin{array}{l}\text { Communication and dealing with people } \\
18\end{array}$ \\
\hline Technical & - & $\begin{array}{l}\text { Professional and economic-legal knowledge } \\
\qquad 19\end{array}$ \\
\hline Personality characteristics & $\begin{array}{l}\text { Responsibility and conscientiousness } \\
\qquad 9\end{array}$ & $\begin{array}{l}\text { Independence and reliability } \\
20\end{array}$ \\
\hline
\end{tabular}

For both managers and staff members, communication and dealing with people are important. Although for most of our characteristics, respondents' job positions were not relevant, we have just used this characteristic for the additional finding of the key professional competencies of the respondents, which they perceive as important for the performance of their work. Having used open questions, we have the opportunity to find out their views on the personality characteristics, knowledge and skills that are most important to the efficiency of their work. Although the information contained in the managers' reports was essential given the focus of our research, the possibility of comparing and finding differences with the employees' preferences is indeed not without interest. 
The results presented in Table 9 can be made perhaps more illustrative in Figure 1.

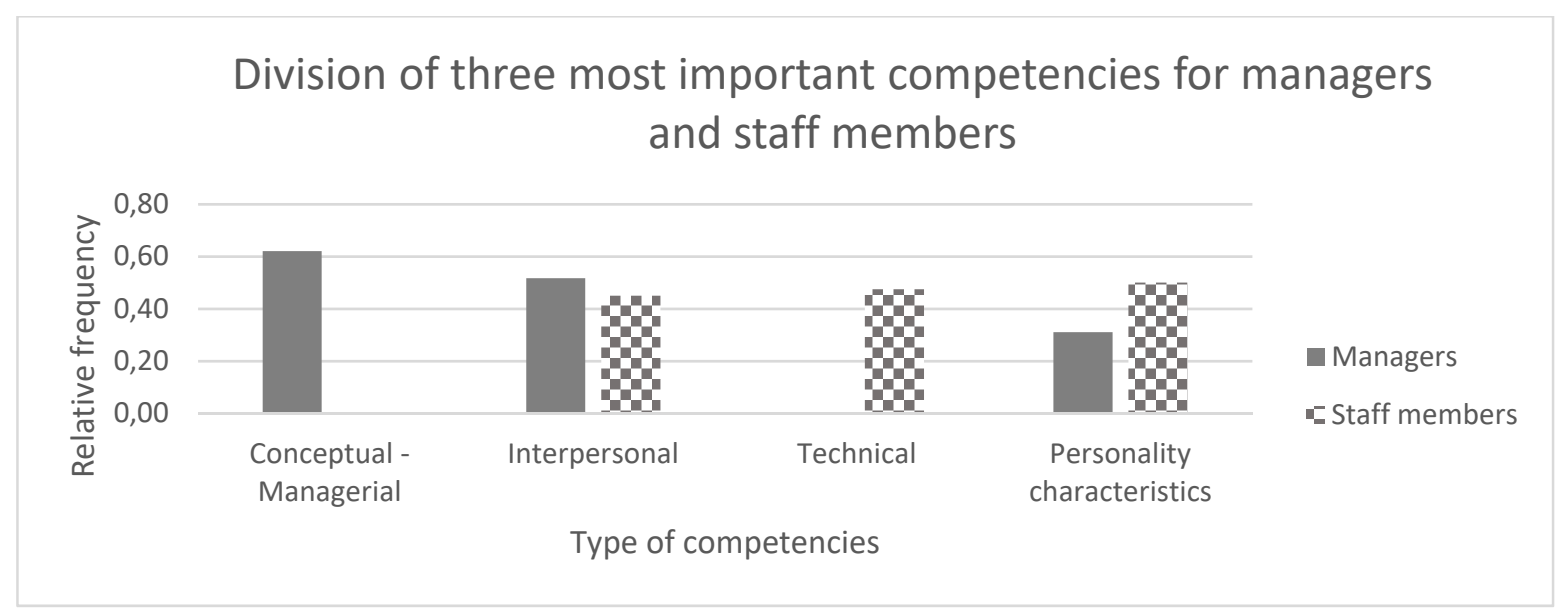

Figure 1. Division of the three most important competencies as perceived by managers and staff members themselves - relative frequencies (source: created by authors)

No managers have marked technical competencies among the three most important ones, while, on the other hand, the same holds for conceptual-managerial competencies in the case of staff members. Note that in the Personality characteristics type two slightly different characteristics were merged in the graph. For the group of managers, it was "Responsibility and conscientiousness" while for the staff members it was "Independence and reliability".

\section{Discussion of results}

Research on the impact of employees' training and development activities on the performance of an organisation is usually associated with private sector organisations, while, according to Birdi, Patterson and Wood (2007), there exists a large extent unjustified assumption that the same findings will be valid also in other sectors. The authors compare differences in the use of educational practices among for-profit and non-profit organisations and assess them to various organisational performance indicators. In our research, on the other hand, we focused only on training in NPOs, taking into account the specific programs for managers. The main reason is that as previous research confirms (Agle, Nagarajan, Sonnenfeld, \& Srinivasan, 2006; Siegel, Waldman, Atwater, \& Link, 2004), leaders are important from an organisation's point of view, with a significant influence on the performance of the organisation. This is also reflected in the level of investment in managers' development (Martineau \& Hannum, 2003). Our previous research (Míková, Komárková, \& Pudil, 2017) also confirmed a relationship between the amount of investment in education and the size of the organisation. Therefore, in the case of this research, the size of the organisation was one of the monitored characteristics explaining the existence of managerial education. The differences in the existence of education for managers with respect to this variable were statistically significant $(p=0.012)$.

Another investigated characteristic of our research related to the existence of training for managers in the organisation was the type of founder and the related area of interest. Inspiration has been found from the study of McDermott et al. (2011), which points out that individual development of leaders is greatly influenced not only by their personality characteristics, emotional intelligence but also by the environment in which they operate - the sectoral context. Notably, the social context and organisational culture can be considered as having a robust contextual influence. The above findings are undoubtedly related to the fact that who is the founder of the organisation. In particular, he will co-develop the structure and also the culture of the organisation linked to the structure.

Furthermore, we investigated the contextual influence of the environment on the activities of non-profit managers mentioned by McDermott et al. (2011) concerning another characteristic, which is the sector of economic activity. However, the cross-sectional difference in our research has not been evaluated as statistically significant. The fact that from the research sample just educational institutions pay the least attention to the training of managers may be associated with the fact that in educational institutions are employees selected into leading positions not by prior training to acquire managerial competencies. The selection (election or appointment) is made by their scholarly erudition and professional qualities (e.g. officials at universities), or they are appointed by the founder (heads of secondary and primary schools). More attention is paid to managerial education programs in public administration and other services (Administration, Other). Organisations operating in these sectors are more likely to be engaged in managerial education, and managers are more systematically prepared for leadership positions through development and skills growth programs with a high probability of selecting candidates from among their staff.

One of the characteristics examined was also the duration of activity. It could have been expected that NPOs, with a relatively short history of their operation, would have less time to start organising training for their managers: Therefore, their rate of existence of this training would be perhaps lower in comparison to well-established NPOs with 
much longer duration of the operation. However, the impact of duration of activity on the existence of special education for managers has not been found in our study $(\mathrm{p}=0.569)$. On the other hand, it should be noted that the results confirming the connection between the size of the organisation, the type of founder and the education for managers can be somewhat influenced by the fact that the founder of large organisations in our country is usually the government (state or local). Also, the participation at development programs is for officials and civil servants of state administration and self-government regulated by law.

An essential component of the process of continuing education in organisations is not only an analysis of needs, planning, realisation but also its evaluation, i.e., monitoring the results of education. According to Birdi, Patterson, and Wood (2007), in the case of NPOs, employees are more often involved in special education and development programs than in for-profit organisations. However, as regards group learning, strategic needs analysis, and evaluations, the differences between profit and non-profit organisations were not found. Individual learning practices have been more closely tied to performance in NPOs, while team learning has been more important for-profit companies. The last characteristic of our research, investigated in relation to education and development in non-profit sector organisations, was, therefore, their evaluation. In this, we were inspired by the publication "Training Evaluation in the Public Sector" written by Phillips (2003). Increasing pressures on public sector organisations lead to higher interest in development and education programs and related processes, including employer-sponsored training. At the same time, the author draws attention to the lack of research into the use of education assessment models in public sector organisations. She provides a framework for evaluating education in public sector organisations and prescribes some solutions to overcome barriers that currently hamper the implementation of a comprehensive assessment, including ROI.

As Phillips (2003) stated, survey results showed that training in public sector organisations had been mainly at Level 1 (Reaction) and Level 2 (Learning) using the Phillips Five-Step Framework. Some progress was also recorded at other levels ( 3 - impact on behaviour, 4 - results, 5 ROIs) but she noted that the public sector was less used to use all the levels than the private sector. From these findings, our research has focused on the less-investigated fourth level of education evaluation, aimed at the results and effects projected on the work of the staff and their performance. Our results showed a statistically significant relationship $(p=0.009)$ between the implementation of managerial education programs in the organisation and evaluation of the results of education (Level 4) in the organisation. The questionnaire was designed to provide more detailed information as to whether the reviewed evaluation also includes key indicators from which the effects associated with manager training can be indeed discerned.

The evaluation of the organisation's education in terms of the impact on the results of the work was further investigated in more detail, namely which indicators of the impacts are assessed. To determine the appropriate indicators associated with employee skills reflecting the various areas of organization prosperity, we were inspired by the Balanced Scorecard (BSC) methodology (Kaplan \& Norton, 1996), a strategic management and performance measurement system that assesses success in terms of financial perspectives, customer, process, and learning and growth. Therefore, the indicators specified by us in the questionnaire, which the participants of our research could designate by ticking some of them, covered all the above areas. The results indicate that NPOs in our research, when they have development programs for managers and assess their effects on the organization's results, most often use for this purpose the following indicators: time spent in education, the skills of the employees and the number of certificates obtained in the required fields, employee motivation index, employee satisfaction and loyalty, employee turnover. These are therefore indicators of the learning and growth perspective, which in principle correspond to the objectives and the main requirements for the results of the further education of the managerial positions.

Training of managers is closely related to the addition or extension of their key competencies. It should be stressed here that our aim was not to investigate what competencies are developed by training programs for NPOs managers but to find out which competencies they consider themselves as the most important ones. By complementary research, therefore, a content analysis of the answers of the NPO managers to the question which three competencies they would identify as most important for their work was performed. The following competencies were found:

- decision-making and management;

- communication and dealing with people;

- responsibility and conscientiousness.

This is not in contradiction with the findings of McDermott et al. (2011) but corresponds even to the results by Thach and Thompson (2007) in the field of personality characteristics (honesty and integrity) and above all with the requirement for teamwork.

Competencies are the central concept in the article by Vrchota and Kajanová (2014). The authors define managerial competencies within the private non-profit sector with subsequent comparison with the commercial sphere. While co-operation and autonomy were found as critical features, similarly in our research, the lowest value was reached by creativity, which is a competence almost not existing in our research. The group of surveyed staff members identified the necessary managerial competencies as follows: professional and economic-legal knowledge; communication and dealing with people; independence and reliability. Even the performed comparison of managers and the staff concerning their opinion on the key professional competencies is not without interest. Employees' (the staff members') preferences have only marginally touched the competencies falling within the area of managerial competencies defined by Katz (2009) or Tureckiová (2009), but they were in the area of personal and technical competencies. 
On the other hand, the group of managers did not mark the technical skills among the three most important managerial competencies. The reason may be in the fact that these competencies are closely related to the corresponding qualifications (formal education) that most managers already fulfil when taking up employment. It is also worth mentioning that both groups - managers and staff - agree on the need for interpersonal competencies in the form of communication, teamwork, and dealing with people.

\section{Conclusions}

The paper dealt with the issue of further professional training of employees/managers in the NPOs. Literature research confirms that the prosperity of the organisation is linked to the quality of human capital in the organisation. Therefore, if we want to contribute to the further development of the organisation, one of the possible ways will be to increase the professional skills of its employees through education and development programs.

By research question RQ1, organisational learning for managers, that is for those who determine the future direction and achievement of its goals, was evaluated in our research in relation to selected characteristics of NPO (size, type, sector of economic activity, duration of economic activity). Our findings showed a statistically significant relationship between the training programs for managers and the size of the organisation $(p=0.008)$. However, it is necessary to add that the fact that large organizations almost twice more often implement this type of education can also be related to the fact that large organizations generally invest more in development activities, they are involved in the planning, implementation and evaluation of education as an integral part of the long-term strategy (Míková, Komárková, \& Pudil, 2017). To strive for the educational and development programs to focus on the specifics of the organisation and to meet the specific needs of the employees, managers should be a requirement for every NPO regardless of its size and the type according to its founder. This can be amplified by the finding (Kopfová, 2012) that public administration organisations that do not have a prepared and approved strategy have usually a poor management level, and the emphasis is placed on operational activities.

The results further confirm a statistically significant relationship $(p=0.007)$ between training for managers and evaluating the impacts of learning on the results of the NPO. The importance of evaluating educational programs is, therefore, unquestionable. Furthermore, our contribution shows that training programs for NPO managers should be evaluated on the level of the impacts of education on the results of the activity. This answers research question RQ2. As far as research question RQ3 is concerned, NPO managers consider the following three competencies to be the most important: decision-making, communication and dealing with people, and responsibility and conscientiousness. The differences in comparison with staff members' preferences are presented in the previous section.

Fulfilling the organisation's goals and their compliance with the expected results of the organisation's educational strategies can be assessed using key performance indicators of the organisation. This can demonstrate how the skills acquired by education have reflected in activities that bring optimum results to the organisation. Thus, areas, where development strategies do not yet have the expected effects, can be identified, and in that direction to focus further education of NPOs in the future. However, the content of the training programs must also correspond to the actual needs of the employees themselves, who will best assess the competencies they need to work effectively.

\section{Limitation of research}

As mentioned above, a certain limitation of the research is a smaller number of organisations in this study. Currently, the sample size is being extended. Besides, the results might have also been affected by the fact that the civil servants in the Czech Republic (as opposed to education, health care or other non-profit organisations) have special training of managers legislatively enshrined and are usually employed in a large organisation. This fact could somehow distort the results of the investigation.

\section{Funding}

This work was financially supported by the Internal Grant Agency of the University of Economics, Prague, under grant [number IGS F6/24/2018]. Furthermore, the authors thank the Joint Laboratory SALOME 2 for valuable non-financial support.

\section{Disclosure statement}

Authors declare that they have no competing financial, professional, or personal interests from other parties.

\section{References}

Agle, B. R., Nagarajan, N. J., Sonnenfeld, J. A., \& Srinivasan, D. (2006). Does CEO charisma matter? An empirical analysis of the relationships among organizational performance, environmental uncertainty, and top management team perceptions of CEO charisma. Academy of Management Journal, 49(1), 161-174. https://doi.org/10.5465/amj.2006.20785800 
Birdi, K. S., Patterson, M. G., \& Wood, S. J. (2007). Learning to perform? A comparison of learning practices and organizational performance in profit-and non-profit-making sectors in the UK. International Journal of Training and Development, 11(4), 265-281. https://doi.org/10.1111/j.1468-2419.2007.00285.x

Boyatzis, R. E. (1982). The competent manager: A model for effective performance. USA, New York: John Wiley \& Sons.

Boyle, F. M., Donald, M., Dean, J. H., Conrad, S., \& Mutch, A. J. (2007). Mental health promotion and non-profit health organisations. Health \& Social Care in the Community, 15(6), 553-560. https://doi.org/10.1111/j.1365-2524.2007.00712.x

Caras, A., \& Sandu, A. (2014). The role of supervision in professional development of social work specialists. Journal of Social Work Practice, 28(1), 75-94. https://doi.org/10.1080/02650533.2012.763024

Carpenter, J., Webb, C., Bostock, L., \& Coomber, C. (2012). Effective supervision in social work and social care. Bristol: Social Care Institute for Excellence.

Čermáková, K., \& Johnová, M. (2002). Zaváděni standardů kvality sociálních služeb do praxe. Průvodce poskytovatele. Praha: MŠMT.

Drucker, P. F. (2002). To nejdůležitějšsi z Druckera v jednom svazku. Management Press.

Fuxová, Z. (2011). Vzdélávání pracovniků v neziskových organizacich. Diploma thesis. Praha: Charles University, Faculty of Arts.

Gabčanová, I. (2012). Human Resources Key Performance Indicators. Journal of Competitiveness, 4(1), 117-128. https://doi.org/10.7441/joc.2012.01.09

Giffords, E. D. (2009). An examination of organizational commitment and professional commitment and the relationship to work environment, demographic and organizational factors. Journal of Social Work, 9(4), 386-404. https://doi.org/10.1177/1468017309346232

Gold, J., Thorpe, R., \& Mumford, A. (2010). Leadership and management development. UK, London: Kogan Page Publishers.

Goleman, D. (2006). Working with emotional intelligence. Bantam trade paperback reissue. New York: Bantam Books.

Hay, K., \& Brown, K. (2015). Social work practice placements in Aotearoa New Zealand: Agency managers perspectives. Social Work Education, 34(6), 700-715. https://doi.org/10.1080/02615479.2015.1062856

Hardina, D., \& Montana, S. (2011). Empowering staff and clients: Comparing preferences for management models by the professional degrees held by organization administrators. Social Work, 56(3), 247-257. https://doi.org/10.1093/sw/56.3.247

Ismaili, M., \& Latifi, V. (2012). The impact of education on the transparent and democratic function of public administration. Procedia-Social and Behavioral Sciences, 46, 4731-4735. https://doi.org/10.1016/j.sbspro.2012.06.326

Kadushin, A., \& Harkness, D. (2014). Supervision in social work (5th ed.). Columbia University Press. https://doi.org/10.7312/kadu15176

Kaplan, R. S., \& Norton, D. P. (1996). The balanced scorecard: Translating strategy into action. Harvard Business Review Press.

Katz, R. L. (2009). Skills of an effective administrator. Harvard Business Review Press.

Kerlesová, V. (2010). Zhodnocení efektivity investic do vzděláváni zaměstnanců veřejného sektoru. Pardubice: University of Pardubice, Fakulty of Economics and Administration.

Kirkpatrick, D. L., \& Kirkpatrick, J. D. (2006) Evaluating training programs: The four levels. San Francisco: Berrett-Koehler Publishers.

Kong, E. (2009). Facilitating learning through intellectual capital in social service nonprofit organizations. International Journal of Learning, 16(2), 533-547. https://doi.org/10.18848/1447-9494/CGP/v16i02/46110

Kopfová, A. (2012). Strategie a její implementace v organizacích veřejné správy [Strategy and Its Implementation in Organizations of Public Administration]. Societas et Res Publica, 1(3), 86-97.

Krajáč, P. (2005). Úvod do ř́zení lidských zdrojů. Institut pro místní správu.

Luiz, D. E. C. (2012). The emancipatory dimension of training public policy counsellor managers. In EDULEARN12 Proceedings (pp. 5505-5514). IATED.

Marinič, P. (2008). Plánování a tvorba hodnoty firmy. Praha: Grada Publishing.

Martineau, J. W., \& Hannum, K.M. (2003). Evaluating the impact of leadership development: A professional guide. Center for Creative Leadership, Greensboro, NC.

Matoušek, O. (2003). Metody a řizení sociální práce (1. vyd.). Praha. Portál, 384. ISBN 80-7178-548-2.

McDermott, A., Kidney, R., \& Flood, P. (2011). Understanding leader development: Learning from leaders. Leadership \& Organization Development Journal, 32(4), 358-378. https://doi.org/10.1108/01437731111134643

Molek, J. (2011). Řizeni organizací sociálnich služeb. Praha: VÚPSV.

Mumford, A. (2006). Management Development-strategies for action. Development and Learning in Organizations: An International Journal, 20(2).

Mumford, A., \& Gold, J. (2004). Management development: Strategies for action. CIPD.

Novák, P. (2012). Manažerské kompetence v malých podnicích. Vysoké učení technické.

Phillips, J. (1996). How much is the training worth?. Training and Development, 50(4), 20-24.

Phillips, P. P. (2003). Training evaluation in the public sector. Dissertation Archive. 2404. Retrieved from https://aquila.usm.edu/theses_dissertations/2404

Prahalad, C. K., \& Hamel, G. (1994). Competing for the future (Vol. 25). Boston: Harvard Business School Press.

Prugsamatz, R. (2010). Factors that influence organization learning sustainability in non-profit organizations. The Learning Organization, 17(3), 243-267. https://doi.org/10.1108/09696471011034937 
Mikova, I.; Komarkova, L.; Pudil, P. 2019. Support of development of non-profit organisations through special training programs for their managers

Shanks, E., Lundström, T., \& Bergmark, Å. (2014). Embedded in practice? Swedish social work managers on sources of managerial knowledge. Human Service Organizations: Management, Leadership \& Governance, 38(5), 435-447. https://doi.org/10.1080/03643107.2013.866605

Siegel, D. S., Waldman, D. A., Atwater, L. E., \& Link, A. N. (2004). Toward a model of the effective transfer of scientific knowledge from academicians to practitioners: qualitative evidence from the commercialization of university technologies. Journal of Engineering and Technology Management, 21(1-2), 115-142. https://doi.org/10.1016/j.jengtecman.2003.12.006

Spencer, L. M., \& Spencer, S. M. (1993). Competence at work: models for superior performance. New York: Wiley.

Thach, E., \& Thompson, K. J. (2007). Trading places: Examining leadership competencies between for-profit vs public and nonprofit leaders. Leadership \& Organization Development Journal, 28(4), 356-375. https://doi.org/10.1108/01437730710752229

Tureckiová, M. (2004). Řizeni a rozvoj lidi ve firmách. Praha: GRADA Publishing.

Tureckiová, M. (2009). Rozvoj a ř́zení lidských zdrojů. Univerzita Jana Amose Komenského.

Veteška, J. (2010). Kompetence ve vzděláváni dospělých: pedagogické, andragogické a sociální aspekty. Jan Amos Komenský University Prague.

Vrchota, J., \& Kajanová, A. (2014). Managers' competences in non-profit sector. Acta Academica Karviniensia, 14(4), $108-114$. https://doi.org/10.25142/aak.2014.072 